\title{
POSSIBILITIES TO USE FISH WASTE FOR ENERGY PRODUCTION
}

Virginija SKORUPSKAITÉ, Synthesis Gas, Second Generation Liquid Biofuel and Biohydrogen Laboratory, Institute of Environment and Ecology, Aleksandras Stulginskis University, Studentų str. 11, LT-53361 Akademija, Kauno r., Lithuania. virginija.skorupskaite@asu.lt (corresponding author)

Eglė SENDŽIKIENĖ, Synthesis Gas, Second Generation Liquid Biofuel and Biohydrogen Laboratory, Institute of Environment and Ecology, Aleksandras Stulginskis University, Studentų str. 11, LT-53361 Akademija, Kauno r., Lithuania. egle.sendzikiene@asu.lt Milda GUMBYTÉ, Laboratory of Chemical and Biochemical Research for Environmental Technology, Institute of Environment and Ecology, Aleksandras Stulginskis University, Studentų str. 11, LT-53361 Akademija, Kauno r., Lithuania; milda.gumbyte@asu.lt,

\begin{abstract}
The secondary raw materials of fish can be used for various purposes in food industry, agriculture, etc. No less important way for usage of secondary raw fish, dead fish and fish farming sludge is the utilization of mentioned feedstocks for energy purposes, i.e. biofuels production. In this reearch, the possibilities of the consumption of dead fish and fish farming sludge for biodiesel and biogas production has been studied. The influence of the basic biodiesel production parameters, including the methanol to oil molar ratio, amount of catalyst, temperature and process duration on transesterification yield was determined. The guantitative and gualitative research of biogas production using different substrates such as fish waste, fish farming sludge and substrates composed of fish waste (de-oiled and non de-oiled biomass)+fish farming sludge and fish farming sludge+wastewater sludge was performed. The biodiesel yield higher than $96.5 \%$ could be achieved under the following process conditions: methanol/oil molar ratio $-4: 1$, amount of enzyme content $-7 \%$ from oil mass, temperature $-40^{\circ} \mathrm{C}$, reaction time -24 hours. The highest biogas yield $(1224 \mathrm{ml} / \mathrm{gVS})$ was determined using wet fish waste biomass and mixed substrates consisted of fish waste and fish farming sludge. The results of qualitative biogas research revealed, that biogas produced from both homogeneous and heterogeneous substrates contained more than $60 \%$ of methane. The highest calorific value (app. $70 \%$ of methane) had biogas gained from fish waste biomass.
\end{abstract}

Keywords: biodiesel, biofuels, biogas, fish farming sludge, fish waste

\section{INTRODUCTION}

The fishing industry in the European Union takes relatively high position. More than 6 million tons of fish are caught every year. In Lithuania, the fisheries sector represents less than $1 \%$ of the gross domestic product. Most of the fish in Lithuania are caught in the Baltic Sea, while the Lithuanian inland fish industry is concentrated in the amount of 9 thousand hectares. Ripelines, pikes, sturgeons and other species of fish are also grown without carp. There are over 40 fish processing companies in Lithuania.

Most of the fish caught is used in the food industry. About $40 \%$ of the fish weight comprises fish fillet, and secondary raw materials, such as the fish head, tail, fins, guts and bones can comprise up to $60 \%$ of the fish weigt. The secondary raw materials can be used in food industry, agriculture, for pharmaceutical purposes, etc (Koscelkovskiene, 2012).

The fish farming can become wasteless. By using certain techniques, for various purposes can be used not only the fish, but also the medium in which it was grown. The rising popularity of hydroponics in the same technological line allows to use fish metabolic products for plant cultivation and saving technological resources (Khater et al, 2015). As a fertilizer for crops can also be used aerobically processed fish farming sludge with a goal to improve productivity of soil (Laos et al, 1998). During composting process the temperature is increased till required level for pasteurization and mineralization of organic matter. Composting of fish waste and fish farming sludge as treatment process is used in Norway (Bergheim et al, 1993).

Fadhil et al (2017) investigations of pyrolysis using fish waste showed that under certain condition it is possible to get the pyrolytic oil and bio-char as raw material for production of activated carbon. Enzymes obtained from fish waste can be used as low cost depilatory agent in the leather industry (Saranya et al, 2016).

Other, no less important way for usage of secondary raw fish, dead fish and fish farming sludge is the utilization of mentioned feedstocks for energy purposes, i.e. biofuels production. By applying the thermochemical conversion methods biodiesel from fish oil (Fadhil et al, 2017) and biogas from de-oiled and non de-oiled biomass (Nges et al, 2012) can be produced.

Copyright (C) 2017 The Authors. Published by Aleksandras Stulginskis University. This is an open-access article distributed under the terms of the Creative Commons Attribution License (CC-BY 4.0), which permits unrestricted use, distribution, and reproduction in any medium, provided the original author and source are credited. 
There is some published information about usage of fish farming sludge for biogas production (Gebauer and Eikebrokk, 2006; Gebauer, 2004; Mirzoyan and Gross, 2013). However, there is lack of data about biogas production from fish farming sludge mixed in various proportions with different other materials.

The aim of this study is to investigate the use possibilities of fish oil, which being in the secondary fish materials is unsuitable for the usage in the pharmaceutical industry, for biodiesel production, and biomass left after oil extraction or non de-oiled fish biomass and fish farming sludge for biogas production.

\section{MATERIALS AND METHODS}

As a raw material for reasearch, fish waste and fish farming sludge from the Aquaculture Center of Aleksandras Stulginskis university was used. The investigation of energy production from fish waste were performed using dried and wet feedstock.

The amount of fish oil in fish waste was determined by applying the standard method LST EN ISO 659 Oilseeds- Determination of oil content (Reference method).

Elemental composition of fish waste and fish farming sludge was estimated using CHNS-O Elemental Analyser (Perkin Elmer 2400 Series). Dry fish waste biomass and sludge were placed into the elemental furnace, combusted in a pure oxygen environment at $975^{\circ} \mathrm{C}$, analysed and after that calculated weight percent of every element.

The volatile organic matter content in the fish waste and sludge was determined by drying the raw material at 105 ${ }^{\circ} \mathrm{C}$ to constant weight, and then burned for 2 hours at $550{ }^{\circ} \mathrm{C}$ in a muffle furnace.

The quality parameters of fish oil such as density and viscosity were analysed according standards LST EN ISO 12185:1999 (Crude petroleum and petroleum products - Determination of density - Oscillating U-tube method and LST EN ISO 3104+AC:2000 (Petroleum products - Transparent and opaque liquids - Determination of kinematic viscosity and calculation of dynamic viscosity (ISO 3104:199) respectively. Acid value was estimated by LST EN ISO 662.

Composition of fatty acids in fish waste oil was identified by applying methods described in the standards LST EN ISO 5508 and LST EN ISO 5509.

The experiments of transesterification of fish waste oil were carried out by applying biotechnological method. The research was performed in the laboratory reactor equipped with the refrigerator, the thermometer, the temperature controller and the stirrer (at a constant speed of $200 \mathrm{~min}^{-1}$ ). The analytical pure methanol (Lach-Ner) and catalyst Lipozyme RM IM were added into the heated to required temperature oil. The transesterification reaction was carried out under the following conditions: methanol/oil molar ratio - 3:1-12:1, amount of catalyst (enzyme) - 1-20\% from oil mass, temperature $-20-60^{\circ} \mathrm{C}$, reaction time $-2-32$ hours. Reaction product after transesterification process was separated from glycerol by decantation, washed with $5 \%$ phosphoric acid solution and distilled water, dried at $105{ }^{\circ} \mathrm{C}$ temperature and additionally with silica gel, and then purified by filtration. The content of methyl esters was estimated applying gas chromatography method, according to the standard LST EN 14203.

De-oiled fish waste cake, fish waste biomass (wet and dried) and fish farming sludge were used for biogas production. Fish waste and fish farming sludge were used in varies proportions, about $0.25 \mathrm{~g}$ of volatile organic material was taken for each sample. In addition, the investigation of biogas production was carried out using the composite substrate consisting of fish farming sludge and wastewater treatment sludge. The heterogeneous substrate was prepared by increasing the substrate's one component by every $10 \%$, while the other one was reduced to the same amount in order to maintain the same amount of organic matter. In such way prepared biomass was mixed with 30 ml digested wastewater treatment sludge purchased from JSC "Kauno vandenys" and placed into the $100 \mathrm{ml}$ graduated syringes that perform the biogas reactor function. Anaerobic conditions were formed by excluding air from the syringes. The investigation of biogas production was performed in thermostatically controlled laboratory shaker at $37{ }^{\circ} \mathrm{C}$ mesophilic temperature. The biogas production process was monitored for around 30 days periodically (every 1-2 days) by measuring the volume of produced biogas and analyzing the biogas composition with the Clarus 580 GC (Perkin Elmer) gas chromatograph with a thermal conductivity (TCD) detector.

\section{Results and discussion}

The results of oil content investigation showed that fish waste contains app. $40 \%$ oil. Examination of oil composition showed that fish waste oil consists mainly of monounsaturated fatty acids. The highest content of saturated fatty acids is palmitic acid (8.8\%), monounsaturated and polyunsaturated - respectively, olein (49.6\%) and linoleic acids $(9.42 \%)$. Compared to rapeseed oil as conventional feedstock of biodiesel production, the similar amount of monounsaturated acids dominates in fish waste oil.

Extracted oil was used for further investigation. Some quality parameters of oil were determined. Density of fish waste oil at $15{ }^{\circ} \mathrm{C}$ reached $0.965 \mathrm{~kg} \mathrm{~m}^{-3}$, while viscosity at $40{ }^{\circ} \mathrm{C}$ was $214.48 \mathrm{~mm}^{2} \mathrm{~s}^{-1}$. The results of analysis showed acid value $11.06 \mathrm{mg} \mathrm{KOH} / \mathrm{g}$.

Investigations of biodiesel production from fish waste oil were carried out using a biotechnological method. Enzyme Lipozyme RM IM was used for this study. The results of the biodiesel production studies showed that the highest yield of methyl esters of fish oil was obtained under the following conditions: methanol/oil molar ratio - 4:1, amount of enzyme content $-7 \%$ from oil mass, temperature $-40{ }^{\circ} \mathrm{C}$, reaction time -24 hours. The highest yield of methyl esters by given values of mentioned reaction parameters reached $96.78 \%$. This value satisfied the methyl esters yield requirements of European standard EN 14214. 
Biogas production using fish waste biomass (de-oiled and non- de-oiled) and fish farming sludge was investigated in this study. One of the most important factor in biogas production process is the ratio of carbon and nitrogen $(\mathrm{C}: \mathrm{N})$ in the substrate. The results of elemental composition of fish farming sludge showed that amount of nitrogen being in the mentioned sludge is similar to the amount of nitrogen in the wastewater treatment sludge (Table 1). Carbon content fixed in the fish farming sludge is higher $20 \%$, while hydrogen content is $50 \%$ higher compared to wastewater sludge.

Table 1. Elemental composition of different origin sludges

\begin{tabular}{|c|c|c|c|}
\hline Feedstock & C, \% & N, \% & H, \% \\
\hline Fish farming sludge & $33.25 \pm 2.7537$ & $2.84 \pm 0.3606$ & $1.97 \pm 0.8134$ \\
\hline Wastewater sludge & $26.53 \pm 4.7333$ & $2.61 \pm 0.6272$ & $0.90 \pm 1.4896$ \\
\hline
\end{tabular}

According to researchers A. Schnürer and A. Jarvis (2009), the process of biogas production proceeds well when $\mathrm{C}: \mathrm{N}$ ratio in the feedstock ranges from 10 to 30. The increasing $\mathrm{C}: \mathrm{N}$ ratio from 10 to 30 stimulates the formation of methanogenesis. In our study C:N ratio in fish farming and wastewater sludges reached 10.2 and 11.78, respectively. In view of these results, it can be stated that fish farming sludge can be used as a feedstock for biogas production without any additional additives.

There were performed quantitative investigations of biogas production using homogeneous (fish waste, fish farming sludge and wastewater sludge) and heterogeneous substrates (fish waste+fish farming sludge). Talking about fish farming sludge, it should be noted that fish farming sludge has a significantly lower dry matter content (app.0.3-4 \%) compared with fish waste. The fractions of substrates were mixed in various ratios. The highest biogas content (1149 $\mathrm{ml} / \mathrm{gVS}$ ) was obtained by increasing the amount of fish waste in the substrate to $90 \%$. The addition of fish waste (FW) to fish farming sludge (FFS) and its increase from from 10 to $90 \%$ resulted in a significant increase in the amount of biogas produced from (substrate: FFS60 \% / FW40 \%) $624 \mathrm{ml} / \mathrm{gVS}$ to $1149 \mathrm{ml} / \mathrm{gVS}$ (substrate: FW $90 \%$ / FFS $10 \%$ ). The amount of produced biogas was almost unchanged (ranged within $3 \%$ ) by decreasing of amount of fish waste in the substrate from 30 to $0 \% .1224 \mathrm{ml}$ of biogas was obtained from $1 \mathrm{~g} \mathrm{VS}$ of wet fish waste biomass. Comparing biogas amounts, obtained from fish waste with biogas amount, gained from wastewater sludge (WWS), it was observed that 1.91 times more biogas was obtained from fish waste than using wet wastewater sludge. The results of investigation showed that yield of biogas produced from wastewater sludge is higher about $7 \%$ comparing to biogas yield gained from fish farming sludge (Fig. 1).

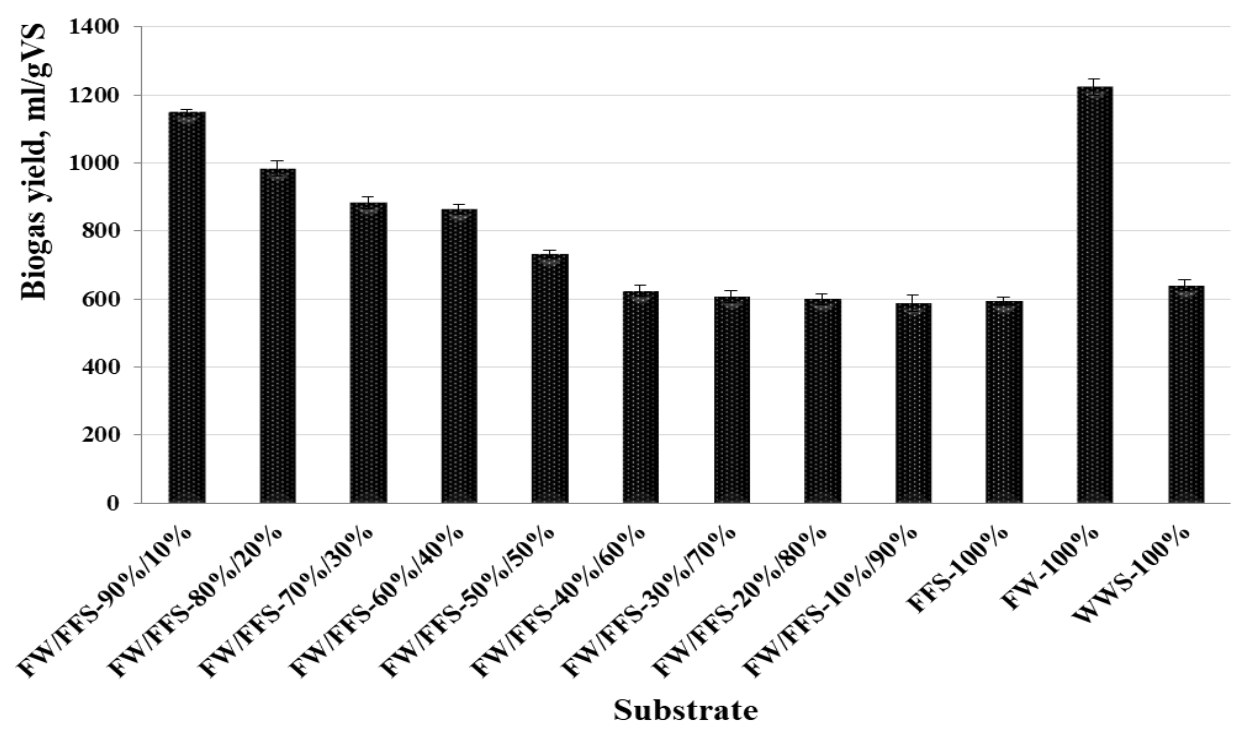

Figure 1. Biogas yield using fish waste and fish farming

Dry de-oiled fish waste biomass also can be used for biogas production as an integral part of heterogeneous substrate. As it can be seen from research results, yield of biogas produced from fish waste biomass is app. $40 \%$ higher comparing with yield of biogas produced from de-oiled fish waste biomass (Fig. 2). The addition of de-oiled fish waste to the fish farming sludge substrate and increasing its amount proportionally every $10 \%$ to $90 \%$ makes it possible to improve the quantitative characteristics of biogas yield from 1.5 to $23 \%$. 


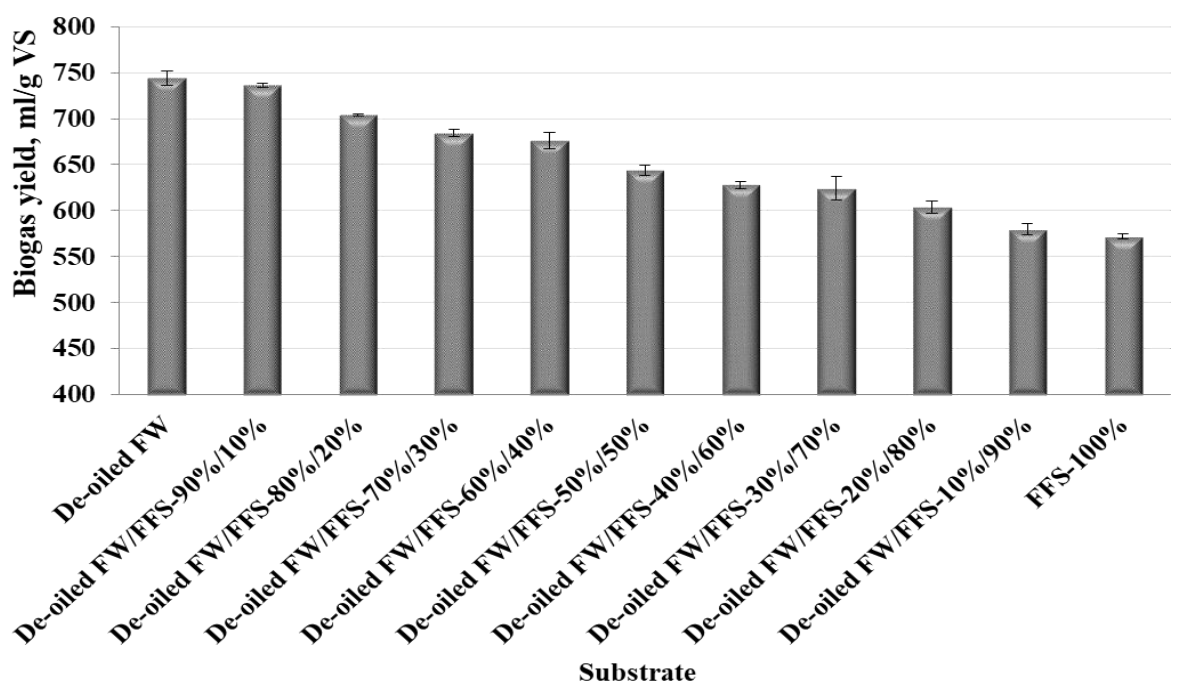

Figure 2. Biogas yield using de-oiled fish waste biomass and fish farming

The results of addition of fish farming sludge to the conventional feedstocks such as wastewater sludge in various ratios showed that even increasing of amount of fish farming sludge in the substrate and reducing the amount of wastewater sludge proportionately does not affect significantly the yield of biogas (Fig. 3). Higher amount of fish farming sludge in the substrate up to $30 \%$ determines $1.3 \%$ lower biogas yield than the yield of biogas derived from the substrate consisting of $100 \%$ wastewater sludge. The increasing of content of fish farming sludge up to $90 \%$ in the substrate reduces biogas yield from $622 \mathrm{ml} / \mathrm{gVS}$ to $586 \mathrm{ml} / \mathrm{gVS}$.

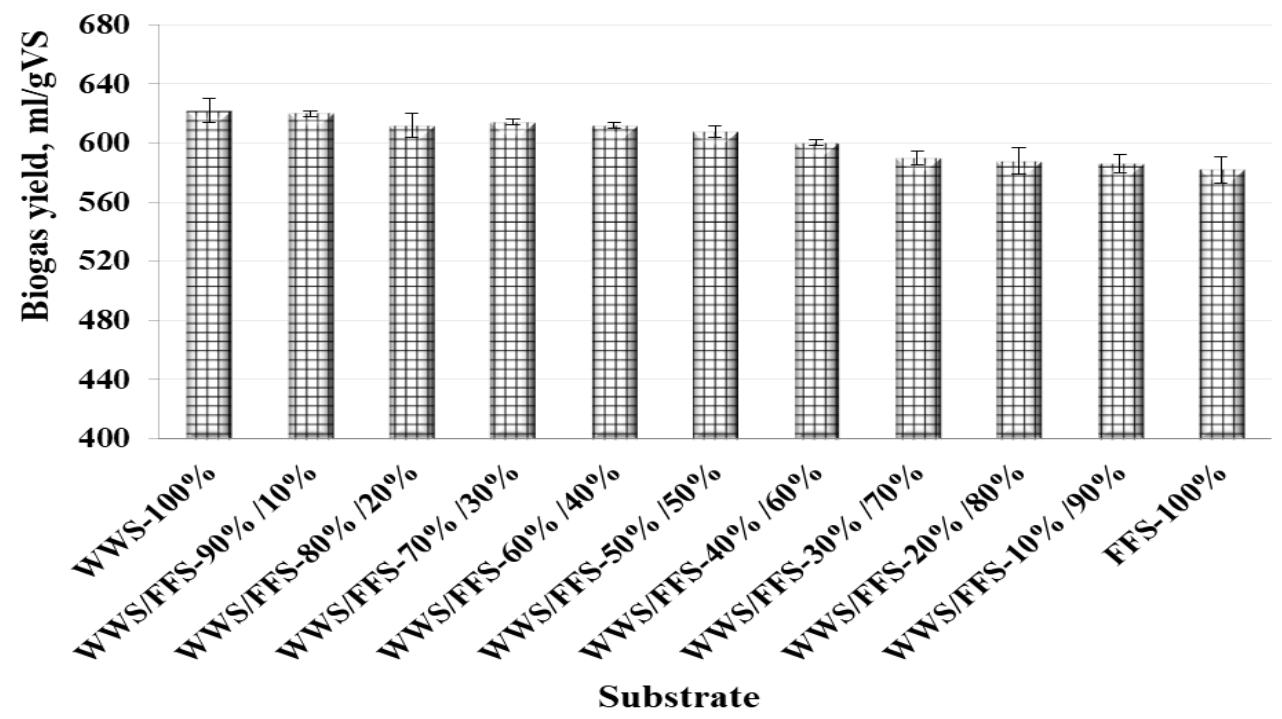

Figure 3. Biogas yield using wastewater sludge and fish farming sludge

Talking about composition of biogas produced from different substrates, it should be noted that from homogeneous (fish waste, de-oiled fish waste, fish farming sludge and traditional biogas raw material - wastewater sludge) and heterogeneous (fish waste + fish farming sludge, de-oiled fish waste + fish farming sludge and wastewater sludge + fish farming sludge) substrates produced biogas contained more than $60 \%$ of methane. Such biogas is defined as quite calorific gas. The other major part of biogas composes carbon dioxide (from 29 to $36 \%$ ) and only small part of the composition is occupied by other impurities $\left(\mathrm{N}_{2}, \mathrm{O}_{2}\right.$ and $\left.\mathrm{H}_{2} \mathrm{~S}\right)$. Hydrogen sulfide was not detected in all samples and its amount ranges from 0.001 to $0.002 \%$. Such amounts of hydrogen sulfide are not high and it is not needed to be removed from biogas in a case of sing biogas in CHP plants. The highest content of methane ( $70 \%)$ was fixated in biogas produced from fish waste (Fig. 4). The higher amount of methane in the mentioned biogas conditions oil beeing in the fish waste biomass. 


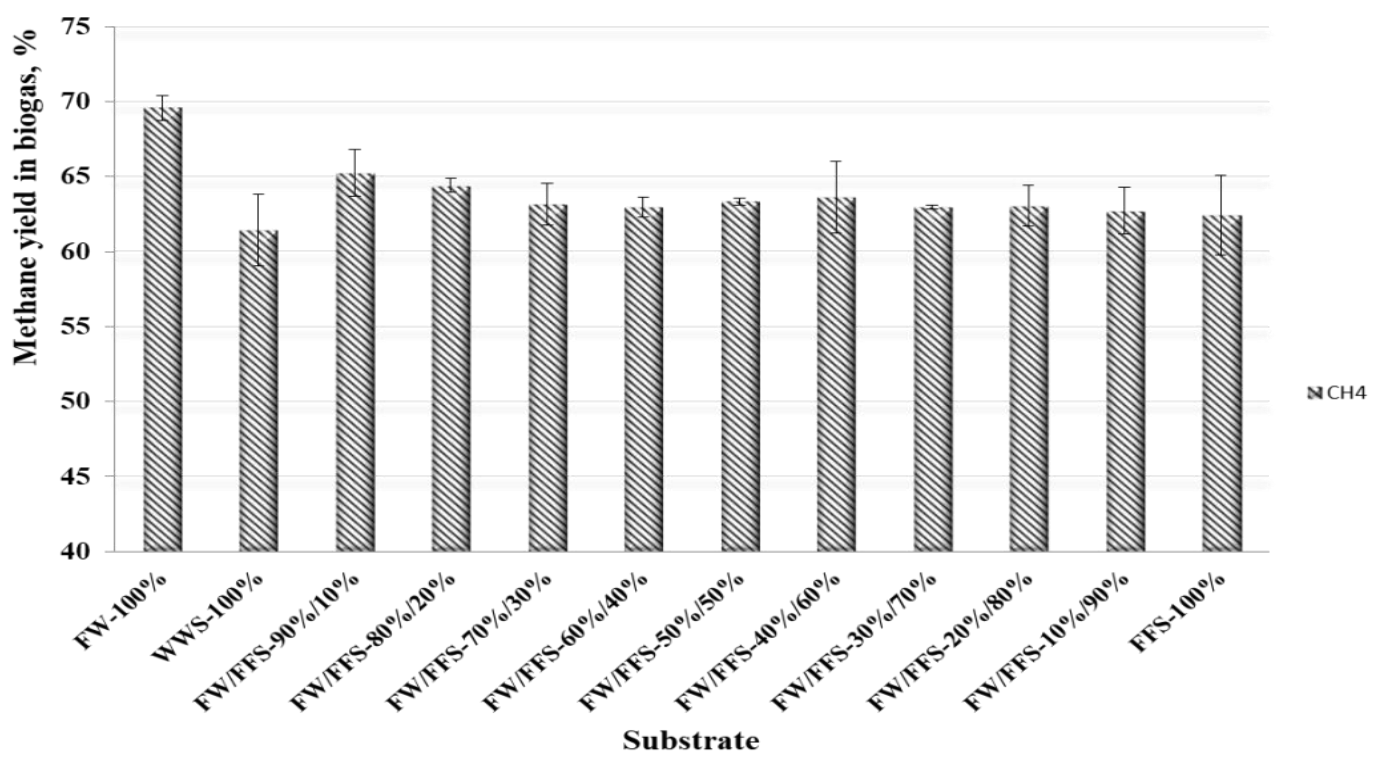

Figure 4. Quality parameters of biogas produced from different substrates

Biogas gained from de-oiled fish waste biomass has app. $5 \%$ lower content of methane compared with biogas produced from fish waste. Methane content in biogas produced from substrate containing de-oiled fish waste and fish farming sludge ranged from 62.6 to $64.6 \%$. The increasing of part of fish farming sludge in the substrate slightly reduces content of methane in biogas. Methane content in biogas produced from wastewater sludge varied in the range of $60-$ $64 \%$. Biogas produced from fish farming sludge, in which the methane content ranged from 62 to $65 \%$ does not concede with its heat value. By mixing sewage and fish farming sludge as a substrate for the production of biogas and gradually increasing the amount of fish farming sludge, it is possible to improve slightly quality parameters of biogas.

Summarizing the results of the research, it can be stated that fish waste and fish farming sludge can supplement the potential of conventional feedstock for biogas production. The use of fish waste for energy enables to increase the potential of renewable energy sources, thereby extracting a double effect: the energy and environmental benefits.

\section{CONCLUSIONS}

1. The optimal conditions for transesterification of wish oil using catalyst Lipozyme RM IM are the following: methanol/oil molar ratio $-4: 1$, amount of enzyme content $-7 \%$ from oil mass, temperature $-40{ }^{\circ} \mathrm{C}$, reaction time 24 hours.

2. The highest biogas yield $(1224 \mathrm{ml} / \mathrm{gVS})$ is produced from non de-oiled fish waste.

3. Extraction of oil from fish waste decreases quantitive parameters of biogas production app. $39 \%$.

4. Yield of biogas, produced from fish farming sludge is app. $6 \%$ lower compared with yield of biogas gained from wastewater.

5. Methane content in biogas produced from homogeneous and heterogeneous substrates consisting of fish waste, fish farming sludge and wastewater sludge is higher than $60 \%$.

\section{REFERENCES}

1. Bergheim, A., Kristisnsen, R., Kelly, L. 1993. Treatment and utilization of sludge from landbased farms for salmon. Techniques for Modern Aquaculture. Proceeding of an Aquacultural Engineering Conference, p. 486-495.

2. Fadhil, A.B., Ahmed, A.I., Salih, H.A. 2017. Production of liquid fuels and activated carbons from fish waste. Fuel. Vol. 187, pp. 435-445. https://doi.org/10.1016/j.fuel.2016.09.064

3. Gebauer, R. 2004. Mesophilic anaerobic treatment of sludge from saline fish farm effluents with biogas production. Bioresource Technology. Vol. 93, pp. 155-167. https://doi.org/10.1016/j.biortech.2003.10.024

4. Gebauer, R., Eikbrokk, B. 2006. Mesophilic anaerobic treatment of sludge from salmon smolt hatching. Bioresource Technology. Vol. 97, pp. 2389-2401. https://doi.org/10.1016/j.biortech.2005.10.008

5. Khater, E.S. G., Bahnavasawy, A.H., Shams, A. E-H. S., Hassaan, M.S., Hassan Y.A. 2015. Utilisation of effluent fish farms in tomato cultivation. Ecological Engineering. Vol. 83, pp. 199-207. https://doi.org/10.1016/j.ecoleng.2015.06.010

6. Koscelkovskiene, I. 2012. The usage of valuable secondary raw material of fish in order to make healthy Lithuanian consumer and rational use raw materials. http://www.vartotojai.lt/index.php?id=7643) (accessed 06 Oktober 2017).

7. Laos, F., Mazzarino, M.J., Walter, I., Roselli, L. 1998. Composting of fish waste with wood by-products and testing compost quality as a soil amendment: experiences in the Patagonia region of Argentina. Compost Science \& Utilization. Vol. 6, pp. 59-66. https://doi.org/10.1080/1065657X.1998.10701910 
8. Mirzoyan, N., Gross, A. 2013. Use of UASB reactors for brackish aquaculture sludge digestion under different conditions. Water Research. Vol. 47, pp. 2843-2850. https://doi.org/10.1016/j.watres.2013.02.050

9. Nges, I.A., Mbatia, B., Bjornsson, L. 2012. Improved utilization of fish waste by anaerobic digestion following omega-3 fatty acids extraction. Journal of Environmental management. Vol. 110, pp. 159-165. https://doi.org/10.1016/j.jenvman.2012.06.011

10. Saranya, R., Prasanna, R., Jayapriya, J., Aravindhan, R., Tamil Selvi, A. 2016. Value addition of fish waste in the leather industry for dehairing. Journal of Cleaner Production, Vol. 118, pp. 179-186. https://doi.org/10.1016/j.jclepro.2015.12.103

11. Schnürer A., Jarvis Å. 2009. Microbiological handbook for biogas plants. Swedish gas centre report 2007, pp. 30-47. 